УДК $633.15+631.8$

DOI: $10.36461 / N P .2019 .52 .3 .005$

\title{
УРОЖАЙНОСТЬ ЗЕРНА КУКУРУЗЫ В ЗАВИСИМОСТИ ОТ ЛИСТОВОЙ ПОДКОРМКИ КОМПЛЕКСНЫМИ УДОБРЕНИЯМИ
}

С. А. Семина, доктор с.-х. наук, профессор; И. В. Гаврюшина, канд. биол. наук, доцент

Федеральное государственное бюджетное образовательное учреждение высшего образования «Пензенский государственный аграрный университет», Россия, т. (8412)628151, e-mail: seminapenza@rambler.ru

В статье представлены результаты исследований по влиянию внекорневой обработки посевов растворами комплексных удобрений с микроэлементами в хелатной форме «Азосол 36 Экстра» и «Акварин 5» на элементы структуры и урожайность зерна раннеспелого и среднераннего гибридов кукурузы на различных уровнях корневого питания. В вариантах без минеральных туков при применении комплексных удобрений в фазу 5 листьев количество зерен в початке возросло на 7,0-9,0\%, а при двукратной обработке - на 8,0-9,9\% и большой разницы по гибридам не отмечено. На удобренном агрофоне обработка посевов в фазу пяти листьев кукурузы микроудобрениями позволила увеличить озерненность початка раннеспелого гибрида Ладожский 191 МВ на 7,2-7,5 \%, а двукратное применение повышало озерненность початка на 7,8-8,1 \%. При обработке посевов среднераннего гибрида «Азосол 36 Экстра» прирост полноценных зерен составил 3,0-3,9 \%, причем большее количество зерен сформировалось при применении микроудобрения в фразу пяти листьев кукурузы. «Акварин 5» способствовал увеличению количества зерен в початке на 4,5-5,6 \%, а лучшие результаты получены при двукратном его применении. При внекорневой обработке посевов раннеспелого гибрида комплексными микроэлементными удобрениями в вариантах без минеральных туков масса зерна початка увеличилась на 6,4-11,1 \% при небольшом преимуществе использования «Акварин 5». Применение «Азосол 36 Экстра» на посевах гибрида Роналдинио на естественном агрофоне позволило увеличить массу зерна с початка на 8,39,7\%, обработка «Акварин 5» - на 11,1-13,2 \%, причем большие прибавки получены при двукратном применении хелатированного удобрения. Бинарное применение «Азосол 36 Экстра» на посевах раннеспелого гибрида Ладожский 191 МВ в условиях улучшенного корневого питания способствовало получению с початка дополнительно 8,2 \% зерна. Обработка в фразу пяти листьев и двукратное применение «Акварин 5» увеличивало массу зерна одного початка на 8,6-8,7 \%. На посевах среднераннего гибрида преимущество было также за микроудобрением «Акварин 5». Применение его в фразу пяти листьев увеличивало массу зерна початка на 9,1 \%, а двукратное использование - на 10,1 \%. «Азосол 36 Экстра» обеспечил меньшие прибавки зерна - 5,2-6, 2 \%, причем разница по срокам обработки незначительная. Перспективным для повышения урожайности зерна кукурузы является использование комплексного удобрения с микроэлементами в хелатной форме «Акварин 5» в фразу пяти листьев и двойная внекорневая обработка, способствующая увеличению сбора зерна с единицы площади на неудобренном агрофоне на 9,6-12,4 \%, а при улучшении условий корневого питания - на 7,7-8,8 \%.

Ключевые слова: кукуруза, гибрид, удобрения, микроэлементы, початок, зерно, урожайность.

\section{Введение}

Во многих странах мира зернопроизводство ориентируют на выращивание продовольственного и фуражного зерна, и особое предпочтение в этом плане отдается кукурузе. Приоритетность ее выращивания определили два основных качества возможность постоянного роста урожайности при совершенствовании технологии производства и высокая энергетическая ценность зерна при скармливании большинству сельскохозяйственных животных
[1]. В связи с внедрением в сельскохозяйственное производство скороспелых сортов и гибридов в условиях лесостепи Среднего Поволжья кукуруза стала возделываться на зерно [2-3]. Интерес хозяйств к выращиванию кукурузы на зерно обусловлен не только высокими сборами концентрированного корма с единицы посевной площади, но и тем, что зерно, вводимое в рацион животных, оказывает положительное влияние на привесы, снижает расход кормов на единицу прироста и со- 
кращает сроки откорма [4]. Для повышения урожайности и улучшения качества зерна растениям необходимы как макро-, так и микроэлементы. Многие исследователи отмечают, что продуктивность кукурузы в значительной степени зависит от уровня минерального питания [5-7, 18-19]. Одним из факторов, обеспечивающих увеличение урожайности зерна кукурузы, является применение комплексных водорастворимых удобрений с микроэлементами [8-9]. Они оказывают влияние на хозяйственнобиологические, физиологические и биохимические процессы, протекающие в растениях, a, соответственно, и на продуктивность в целом [10-12]. Растениям требуется небольшое количество микроэлементов, и, именно поэтому, их удобно вносить путем опрыскивания листьев. Это позволяет оперативно воздействовать на растения в критические периоды, когда растения нуждаются в микроэлементах. При внекорневой подкормке питательные элементы попадают непосредственно в ту или иную часть растения, в которой, как правило, наиболее интенсивно протекают жизненные процессы, и именно там чаще всего встречаются недостатки элементов питания. По эффективности этот путь доставки питания в 5-20 (а по некоторым элементам до 100) раз короче традиционного питания - через корень [13-15]. В последние годы широко освоено производство жидких комплексных удобрений с хелатными формами микроэлементов, предназначенных для некорневых подкормок сельскохозяйственных культур. Так как сельскохозяйственные культуры предъявляют различные требования, то производству предлагается широкий ассортимент комплексных удобрений с различным композиционным набором и соотношением макро- и микроэлементов. Одними из таких удобрений являются удобрения серии «Акварин», «Азосол 36 Экстра», однако, влияние их на формирование урожайности зерна кукурузы в условиях лесостепи Среднего Поволжья изучено недостаточно, что и определило цель исследований.

\section{Методы и материалы}

Исследования проводили в 2016-2018 гг. на черноземе выщелоченном тяжелосуглинистом с повышенным содержанием азота, фоссрора и калия, реакция почвенного раствора слабокислая. Полевой опыт был заложен в соответствии с общепринятыми методиками [16-17] в четырехкратной повторности по схеме: фактор А - гибрид: раннеспелый Ладожский 191 МВ (ФАО 190), среднеранний Роналдинио (ФАО 210); фрактор В - удобрение: 1. $\mathrm{N}_{0} \mathrm{P}_{0} \mathrm{~K}_{0}+$ обработка растений водой; 2. $\mathrm{N}_{0} \mathrm{P}_{0} \mathrm{~K}_{0}+$ Азосол 36 Экстра (3,0 л/га): 3. $\mathrm{N}_{0} \mathrm{P}_{0} \mathrm{~K}_{0}+$ Акварин 5 (3,0 л/га); 4. $\mathrm{N}_{110} \mathrm{P}_{70} \mathrm{~K}_{40}+$ обработка растений водой; 5. $\mathrm{N}_{110} \mathrm{P}_{70} \mathrm{~K}_{40}+$ Азосол 36 Экстра; $\mathrm{N}_{110} \mathrm{P}_{70} \mathrm{~K}_{40}+$ Акварин 5; фрактор C срок внекорневой обработки: 1. в фазу пяти листьев; 2. в фазу восьми листьев; 3. в фазу (пяти листьев (3,0 л/га) + восьми листьев $(3,0$ л/га)). Расположение делянок первого и второго порядка систематическое, третьего - рендомизированное. Площадь делянки третьего порядка $28 \mathrm{~m}^{2}$. Посев проводили с междурядьями 70 см. Густота стояния растений 70 тыс./га. Предшественник - озимая пшеница по чистому пару. Минеральные удобрения (аммиачная селитра, нитроаммофос, хлористый калий) в соответствии со схемой опыта вносили под первую предпосевную культивацию. Посев кукурузы проведен 18 мая в 2016 году, 27 мая в 2017 году и 18 мая в 2018 г. Уборка на зерно осуществлялась, соответственно, 10, 25 и 29 сентября. Комплексные удобрения с микроэлементами растворяли в воде (из расчета 200 л/га). Внекорневую обработку посевов комплексными удобрениями выполняли ранцевым опрыскивателем.

Погодные условия в годы исследований значительно различались между собой. Достаточно благоприятные гидротермические условия периода вегетации культуры сложились в 2016 г. (гидротермический коэффициент (ГТК) 1,09), что способствовало получению наибольшей, за годы проведения опыта, урожайности зерна. Условия 2017 г. (ГТК = 0,98) были менее благоприятными. Вегетационный период 2018 г. отличался засушливостью на фоне пониженных температур воздуха (ГТК = 0,40), что не позволило получить хороший урожай зерна кукурузы.

\section{Результаты}

Урожайность зерна кукурузы зависит от количества растений на единице площади, количества початков на растении и выхода зерна с початка. Как показали результаты трехлетних исследований, на процесс формирования генеративных органов большее влияние оказывали условия минерального питания. Установлено, что внекорневая обработка комплексными удобрениями с микроэлементами практически не влияла на количество развитых початков на 100 растений (таблица).

Как показали проведенные измерения, длина початков варьировала в зависимости от года исследований, гибрида и приемов возделывания. Большими линейными размерами отличались початки, полученные в условиях вегетации 2016 г., а при 
недостатке активных температур вегетации 2017- 2018 гг. получены початки меньшей длины. Следует отметить, что в условиях вегетации 2016-2017 гг. большими размерами початка на всех фонах корневого питания отличался среднеранний гибрид Роналдинио, а при недостатке влаги и тепла в 2018 г. выделился раннеспелый гибрид Ладожский 191 МВ. На всех изучаемых агрофонах прослеживается тенденция увеличения длины початка при фолиарной обработке комплексными удобрениями с микроэлементами, наибольший стимулирующий эффект отмечен при внекорневой обработке «Акварин 5» в фазу пятого листа и двукратном его применении.

Количество зерен в початке является важным элементом структуры урожая. Установлено, что число зерен в початке оп- ределялось особенностями минерального питания, скороспелостью гибрида, а также погодными условиями периода вегетации. Наиболее озернённые початки на всех агрофонах сорормировал раннеспелый гибрид Ладожский 191 МВ. Но, если в 20162017 гг. различия между гибридами были незначительными, то в условиях прохладного засушливого лета 2018 г. разница по гибридам составила 12,8 \% на неудобренном агрофоне и 20,5\% - при улучшении условий корневого питания при преимуществе раннеспелого гибрида. Исследованиями установлено, что внекорневая обработка посевов растворами комплексных удобрений стимулировала формирование полноценного зерна в початке. В среднем за годы проведения опыта, в вариантах без минеральных туков при применении ком-

Элементы структуры урожайности кукурузы

\begin{tabular}{|c|c|c|c|c|c|c|}
\hline \multirow[b]{2}{*}{$\begin{array}{c}\text { Гибрид } \\
\text { (фактор } \\
\text { A) }\end{array}$} & \multirow[b]{2}{*}{ Удобрение (фактор В) } & \multirow{2}{*}{$\begin{array}{c}\text { Срок вне- } \\
\text { корневой } \\
\text { обработки } \\
\text { (фактор С) }\end{array}$} & \multirow{2}{*}{$\begin{array}{c}\text { Количество } \\
\text { початков на } \\
100 \text { расте- } \\
\text { ний, шт. }\end{array}$} & \multicolumn{3}{|c|}{ Початок } \\
\hline & & & & $\begin{array}{c}\text { Длина, } \\
\text { см }\end{array}$ & $\begin{array}{l}\text { Количе- } \\
\text { ство зе- } \\
\text { рен, шт. }\end{array}$ & $\begin{array}{c}\text { Macca } \\
\text { зерна, } \\
\text { г }\end{array}$ \\
\hline \multirow{9}{*}{$\begin{array}{l}\text { Ладож- } \\
\text { ский } \\
191 \text { МВ }\end{array}$} & $\mathrm{NP}_{0} \mathrm{~K}_{0}+$ обработка водой & 5 лист & 101 & 14,1 & 279 & 52,5 \\
\hline & $\mathrm{N}_{0} \mathrm{P}_{0} \mathrm{~K}_{0}+$ обработка водой & 8 лист & 100 & 14,1 & 280 & 51,9 \\
\hline & $\mathrm{N}_{0} \mathrm{P}_{0} \mathrm{~K}_{0}+$ обработка водой & $5+8$ лист & 100 & 13,9 & 280 & 52,8 \\
\hline & $\mathrm{N}_{0} \mathrm{P}_{0} \mathrm{~K}_{0}+$ Азосол 36 Экстра & 5 лист & 100 & 14,4 & 302 & 57,7 \\
\hline & $\mathrm{N}_{0} \mathrm{P}_{0} \mathrm{~K}_{0}+$ Азосол 36 Экстра & 8 лист & 100 & 14,6 & 299 & 55,2 \\
\hline & $\mathrm{N}_{0} \mathrm{P}_{0} \mathrm{~K}_{0}+$ Азосол 36 Экстра & $5+8$ лист & 100 & 14,6 & 307 & 57,7 \\
\hline & $\mathrm{N}_{0} \mathrm{P}_{0} \mathrm{~K}_{0}+$ Акварин 5 & 5 лист & 101 & 14,9 & 304 & 57,6 \\
\hline & $\mathrm{N}_{0} \mathrm{P}_{0} \mathrm{~K}_{0}+$ Акварин 5 & 8 лист & 100 & 14,7 & 301 & 56,7 \\
\hline & $\mathrm{N}_{0} \mathrm{P}_{0} \mathrm{~K}_{0}+$ Акварин 5 & $5+8$ лист & 100 & 15,0 & 307 & 59,0 \\
\hline \multirow{9}{*}{$\begin{array}{l}\text { Ронал- } \\
\text { динио }\end{array}$} & $\mathrm{N}_{0} \mathrm{P}_{0} \mathrm{~K}_{0}+$ обработка водой & 5 лист & 101 & 14,9 & 273 & 51,4 \\
\hline & $\mathrm{N}_{0} \mathrm{P}_{0} \mathrm{~K}_{0}+$ обработка водой & 8 лист & 101 & 14,6 & 272 & 50,7 \\
\hline & $\mathrm{N}_{0} \mathrm{P}_{0} \mathrm{~K}_{0}+$ обработка водой & $5+8$ лист & 101 & 14,9 & 273 & 51,4 \\
\hline & $\mathrm{N}_{0} \mathrm{P}_{0} \mathrm{~K}_{0}+$ Азосол 36 Экстра & 5 лист & 101 & 15,2 & 292 & 56,2 \\
\hline & $\mathrm{N}_{0} \mathrm{P}_{0} \mathrm{~K}_{0}+$ Азосол 36 Экстра & 8 лист & 102 & 15,0 & 288 & 54,9 \\
\hline & $\mathrm{N}_{0} \mathrm{P}_{0} \mathrm{~K}_{0}+$ Азосол36 Экстра & $5+8$ лист & 102 & 15,3 & 295 & 56,4 \\
\hline & $\mathrm{N}_{0} \mathrm{P}_{0} \mathrm{~K}_{0}+$ Акварин 5 & 5 лист & 102 & 15,4 & 297 & 57,1 \\
\hline & $\mathrm{N}_{0} \mathrm{P}_{0} \mathrm{~K}_{0}+$ Акварин 5 & 8 лист & 102 & 15,2 & 293 & 56,6 \\
\hline & $\mathrm{N}_{0} \mathrm{P}_{0} \mathrm{~K}_{0}+$ Акварин 5 & $5+8$ лист & 103 & 15,3 & 300 & 58,2 \\
\hline \multirow{9}{*}{$\begin{array}{l}\text { Ладож- } \\
\text { ский } \\
191 \text { МВ }\end{array}$} & $\mathrm{N}_{110} \mathrm{P}_{70} \mathrm{~K}_{40} 20+$ обработка водой & 5 лист & 104 & 15,9 & 358 & 73,4 \\
\hline & $\mathrm{N}_{110} \mathrm{P}_{70} \mathrm{~K}_{40} 20+$ обработка водой & 8 лист & 103 & 15,8 & 356 & 72,8 \\
\hline & $\mathrm{N}_{110} \mathrm{P}_{70} \mathrm{~K}_{40} \mathrm{~K} 20+$ обработка водой & $5+8$ лист & 103 & 16,0 & 358 & 73,3 \\
\hline & $\mathrm{N}_{110} \mathrm{P}_{70} \mathrm{~K}_{40}+$ Азосол 36 Экстра & 5 лист & 104 & 16,3 & 385 & 78,8 \\
\hline & $\mathrm{N}_{110} \mathrm{P}_{70} \mathrm{~K}_{40}+$ Азосол 36 Экстра & 8 лист & 104 & 16,0 & 380 & 77,5 \\
\hline & $\mathrm{N}_{110} \mathrm{P}_{70} \mathrm{~K}_{40}+$ Азосол 36 Экстра & $5+8$ лист & 106 & 16,5 & 387 & 79,3 \\
\hline & $\mathrm{N}_{110} \mathrm{P}_{70} \mathrm{~K}_{40}+$ Акварин 5 & 5 лист & 106 & 16,7 & 384 & 79,7 \\
\hline & $\mathrm{N}_{110} \mathrm{P}_{70} \mathrm{~K}_{40}+$ Акварин 5 & 8 лист & 105 & 16,2 & 380 & 77,1 \\
\hline & $\mathrm{N}_{110} \mathrm{P}_{70} \mathrm{~K}_{40}+$ Акварин 5 & $5+8$ лист & 106 & 16,8 & 386 & 79,7 \\
\hline \multirow{9}{*}{$\begin{array}{l}\text { Ронал- } \\
\text { динио }\end{array}$} & $\mathrm{N}_{110} \mathrm{P}_{70} \mathrm{~K}_{40}+$ обработка водой & 5 лист & 103 & 16,2 & 336 & 67,1 \\
\hline & $\mathrm{N}_{110} \mathrm{P}_{70} \mathrm{~K}_{40}+$ обработка водой & 8 лист & 103 & 16,3 & 336 & 66,8 \\
\hline & $\mathrm{N}_{110} \mathrm{P}_{70} \mathrm{~K}_{40}+$ обработка водой & $5+8$ лист & 104 & 16,3 & 337 & 67,3 \\
\hline & $\mathrm{N}_{110} \mathrm{P}_{70} \mathrm{~K}_{40}+$ Азосол 36 Экстра & 5 лист & 105 & 16,8 & 349 & 71,2 \\
\hline & $\mathrm{N}_{110} \mathrm{P}_{70} \mathrm{~K}_{40}+$ Азосол 36 Экстра & 8 лист & 103 & 16,6 & 346 & 70,3 \\
\hline & $\mathrm{N}_{110} \mathrm{P}_{70} \mathrm{~K}_{40}+$ Азосол 36 Экстра & $5+8$ лист & 106 & 16,8 & 350 & 71,5 \\
\hline & $\mathrm{N}_{110} \mathrm{P}_{70} \mathrm{~K}_{40}+$ Акварин 5 & 5 лист & 105 & 17,1 & 353 & 73,2 \\
\hline & $\mathrm{N}_{110} \mathrm{P}_{70} \mathrm{~K}_{40}+$ Акварин 5 & 8 лист & 104 & 16,9 & 351 & 72,0 \\
\hline & $\mathrm{N}_{110} \mathrm{P}_{70} \mathrm{~K}_{40}+$ Акварин 5 & $5+8$ лист & 106 & 17,3 & 356 & 74,1 \\
\hline
\end{tabular}


плексных удобрений в фазу пяти листьев количество зерен в початке возросло на 7,0-9,0 \%, а при двукратной обработке - на 8,0-9,9 \% и большой разницы по гибридам не отмечено. Обработка посевов в фазу восьми листьев кукурузы была менее эффективной, озерненность початка увеличилась на 5,9-7,7 \%. Несколько иная закономерность прослеживается на улучшенном фоне корневого питания. Фолиарная обработка посевов в фразу пяти листьев кукурузы растворами хелатных микроудобрений позволила увеличить озерненность початка раннеспелого гибрида Ладожский 191 МВ на 7,2-7,5 \%. Двукратное применение «Азосол 36 Экстра» и «Акварин 5» повышало озерненность початка на 7,8-8,1 \%. Применение комплексных удобрений в фазу 8 листьев на посевах раннеспелого гибрида приводило к росту количества зерен в початке на $6,7 \%$ и значимых различий в зависимости от вида комплексных удобрений не выявлено. Среднеранний гибрид Роналдинио в условиях улучшенного корневого питания оказался менее отзывчивым на применение комплексных удобрений с микроэлементами. Под влиянием обработки посевов «Азосол 36 Экстра» прирост полноценных зерен составил 3,0-3,9 \%, причем большее количество зерен сорормировалось при применении микроудобрения в фразу пяти листьев кукурузы. «Акварин 5» способствовал увеличению количества зерен в початке среднераннего гибри- да на 4,5-5,6 \%, но лучшие результаты получены при двукратном его применении.

Одним из важных структурных показателей урожайности кукурузы является масса зерна с одного початка. Этот показатель зависит как от генотипа гибридов, так и от условий минерального питания и применения микроэлементных удобрений. Как показали полученные результаты, наиболее полновесный початок получен в более благоприятных вегетационных условиях 2016 г. Недостаточное количество активных температур не позволили в условиях 2018 года получить хорошо выполненный початок. Удобрения с микроэлементами в хелатной форме способствовали получению большей массы зерна с початка. Внекорневая обработка посевов раннеспелого гибрида растворами хелатов металлов в вариантах без полного минерального удобрения способствовала увеличению массы зерна початка на 6,4-11,1\% при небольшом преимуществе использования «Акварин 5». Применение «Азосол 36 Экстра» на посевах гибрида Роналдинио позволило увеличить массу зерна с початка на 8,3-9,7\%. При обработке «Акварин 5» прирост составил 11,1-13,2 \%, причем большие прибавки получены при двукратном применении хелатированного удобрения.

Полное минеральное удобрение несколько снижало эффрект внекорневой обработки. В среднем за три года наблюдений бинарное применение «Азосол 36 Экстра» на

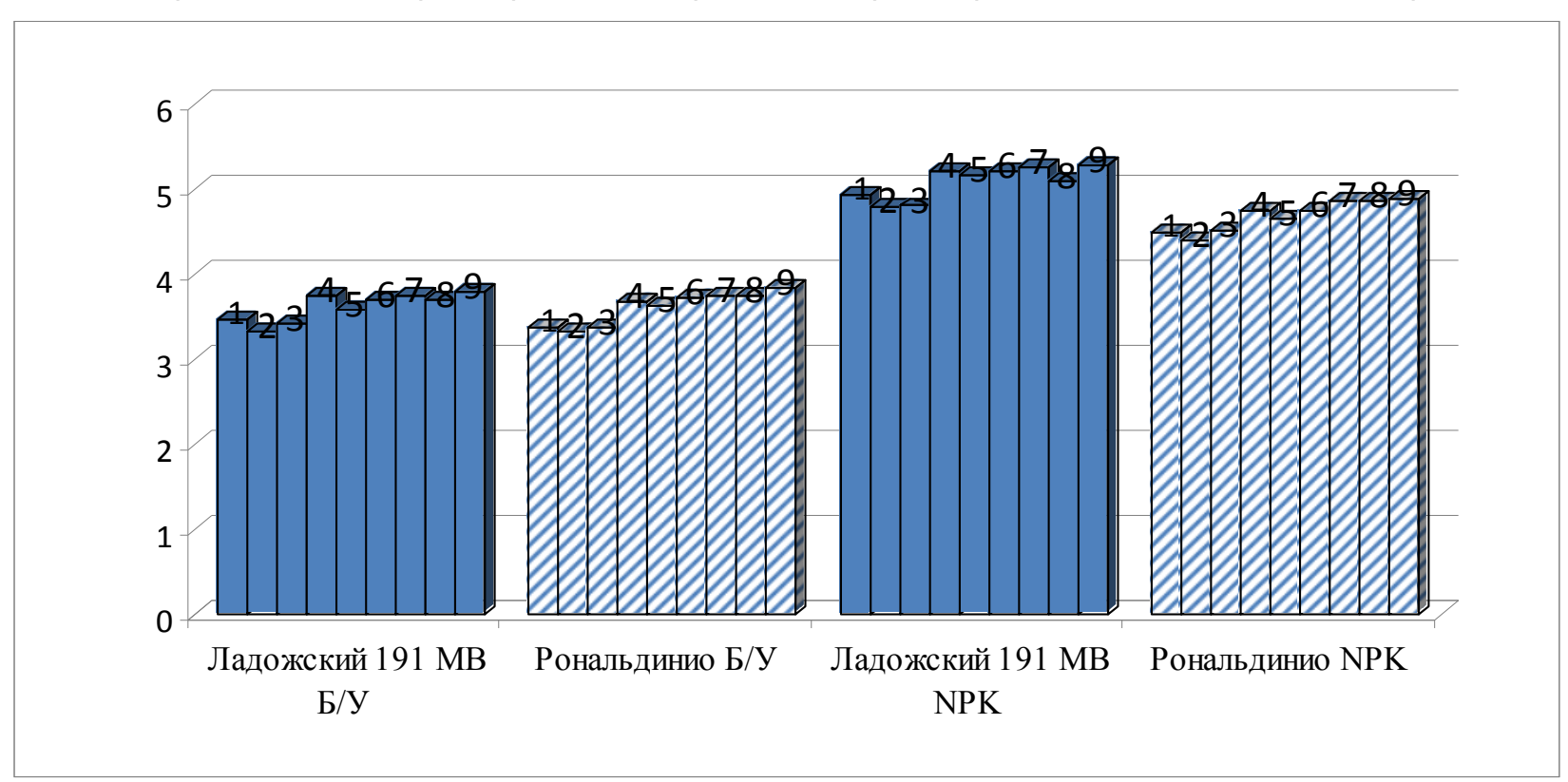

Урожайность зерна кукурузы, среднее за 2016-1018 г2.

Примечание: фрактор А - гибрид: раннеспелый Ладожский 191 МВ, среднеранний Роналдинио; фактор B - удобрение; фрактор C - срок внекорневой обработки: 1 - обработка водой (5 лист); 2 - обработка водой (8 лист); 3 - обработка водой (5 + 8 лист); 4 - Азосол 36 Экстра (5 лист); 5 - Азосол 36 Экстра (8 лист); 6 - Азосол 36 Экстра (5 + 8 лист); 7 - Акварин 5 (5 лист); 8 - Акварин 5 (8 лист); 9 - Акварин 5 (5 + 8 лист) 
посевах раннеспелого гибрида Ладожский 191 МВ в условиях лучшего корневого питания способствовало получению с початка дополнительно 8,2 \% массы зерна. Обработка в фразу пяти листьев и двукратное применение «Акварин 5» увеличивало массу зерна одного початка на 8,6-8,7\%. От обработки посевов в фазу восьми листьев получен прирост 5,9- 6,4%. На посевах среднераннего гибрида преимущество было также за микроудобрением «Акварин 5». Применение его в фазу пяти листьев увеличивало массу зерна початка на 9,1\%, а двукратное использование - на 10,1\%. «Азосол 36 Экстра» обеспечил меньшие прибавки зерна - 5,2-6,2 \%, причем разница по срокам обработки незначительная.

Интегрирующим показателем, характеризующим эффективность изучаемых приемов агротехники, является урожайность. В результате проведенных исследований нами было установлено, что на урожайность кукурузы сильное влияние оказали погодные условия вегетационного периода. В 2016 г., при благоприятных гидротермических условиях периода вегетации кукурузы получена наибольшая в опыте урожайность зерна. В условиях недостатка активных температур 2017 г. и, особенно, 2018 г. при недостаточном увлажнении она была значительно ниже.

В среднем за три года проведения эксперимента для раннеспелого гибрида, при использовании «Азосол 36 Экстра» на фоне естественного почвенного плодородия, прирост урожайности составил 8,0 \%, причем обработка в фазу пяти листьев и двукратное применение были по эффрективности равноценны (рис.). При применении «Акварин 5» прибавка получена больше, в среднем, по срокам обработки, 9,6 \%, а наибольший стимулирующий эффект отмечен при бинарном использовании, обеспечившем получение дополнительно 0,37 т/га зерна или 10,8 \% к варианту без комплексного микроэлементного удобрения.

На агрофоне без минеральных удобрений Роналдинио сформировал большую урожайность при двойной обработке «Ак- варин 5» - 3,84 т/га, что на 13,9 \% превышает вариант без микроэлементного удобрения. Немного уступило ему по эффективности применение микроудобрения в фазу восьми листьев кукурузы. Внекорневая обработка посевов «Азосол 36 Экстра» на этом агрофоне показала примерно равную эффективность по всем срокам применения, прирост урожайности составил 8,9-10,4\%.

С улучшением условий корневого питания прибавки зерна от внекорневой обработки микроудобрениями снижаются. Использование «Азосол 36 Экстра» позволило увеличить сбор зерна гибрида Ладожский 191 МВ в среднем на 7,4\%, а лучшим был вариант с двойной обработкой, где получено дополнительно 0,41 т/га (8,5\% к варианту с обработкой водой). Двукратное применение «Акварин 5» способствовал повышению урожайности на 0,48 т/га (10,0\%), а при однократном применении прибавка составила 6,5-6,7 \%.

На фроне полного минерального удобрения при использовании «Азосол 36 Экстра» урожайность зерна гибрида Роналдинио возросла на 5,1-5,8 \%, а лучшим был вариант с обработкой в фразу пяти листьев. При использовании «Акварин 5» лучшие показатели для среднераннего гибрида зафиксированы при обработке в фазу восьми листьев, прирост составил 10,5\%, а от применения в фазу пяти листьев и бинарном опрыскивании получено дополнительно 8,0 \% зерна.

\section{Заключение}

Таким образом, полученные результаты свидетельствуют, что более отзывчивым на применение удобрений был раннеспелый гибрид. Перспективным для повышения урожайности зерна кукурузы является использование комплексного удобрения с микроэлементами в хелатной форме «Акварин 5» в фразу пяти листьев и двойная внекорневая обработка, способствующие увеличению сбора зерна с единицы площади на неудобренном агрофоне на 9,6-12,4 \%, а при улучшении условий корневого питания - на 7,7-8,8\%.

\section{Лuтература}

1. Дроздова, В. В. Влияние норм и сочетаний минеральных удобрений на урожайность кукурузы и агрохимические показатели плодородия чернозема выщелоченного Западного Предкавказья / В. В. Дроздова, Н. Е. Редина // Научный журнал КубГАУ. - 2016. - № 121(07). - С. 1732-1748.

2. Волков, А.И. Продуктивность раннеспелых гибридов кукурузы в условиях Чувашии / А. И. Волков, Н. А. Кириллов, Л. Н. Прохорова // Кормопроизводство. - 2014. - № 5. - С. 36-37.

3. Прохорова, Л. Н. Совершенствование технологии возделывания кукурузы на зерно в зоне дерново-подзолистых почв Поволжья: диссертация на соискание ученой степени кандидата сельскохозяйственных наук: 06.01.01. - Чебоксары, 2015. - 146 с.

4. Макарцев, Н. Г. Кормление сельскохозяйственных животных: учебник для вузов / Н. Г. Макарцев. - 3-е изд., перераб. и доп. - Калуга: Ноосфера, 2012. - 640 с. 
5. Эффрективность удобрений при возделывании кукурузы на зерно в условиях Южного Нечерноземья: монография / А. А. Моисеев, А. В. Ивойлов, А. В. Сидоров [и др.]. - Саранск: Изд-во Мордов. ун-та, 2018. - 172 с.

6. Никитин, В. В. Разработка нормативной базы потребления элементов питания зерновой кукурузы в Зауралье / В. В. Никитин, В. В. Навальнев // Кукуруза и сорго. - 2016. - № 1. - С. 32-35.

7. Сотченко, В. С. Технология возделывания кукурузы / В. С. Сотченко, В. Н. Багринцева // Вестник АПК Ставрополья. - 2015. - Спецвыпуск № 2. - С. 79-84.

8. Гайсин, И. А. Микроудобрения в современном земледелии / И. А. Гайсин, Р. Н. Сагитова, Р. Р. Хабибуллин // Агрохимический вестник. - 2010. - № 4. - С. 13-14.

9. Микроудобрения на хелатнои $\square$ основе: опыт и перспективы использования / Е. Ю. Гейгер, Л. Д. Варламова, В. В. Семенов [и др.] // Агрохимический вестник. -2017. - № 2. - С. 29-32.

10. Дериглазова, Г. М. Значение некорневой обработки отдельными микроэлементами и комплексными удобрениями посевов зерновых культур / Г.М.Дериглазова, О. А. Митрохина, Н. Н. Боева // Агрономия. - 2010. - № 4. - С. 45-47.

11. Сидельников, Н. И. Особенности применения микроудобрений на лекарственных культурах / Н. И. Сидельников, Р. Р. Тхаганов, Ф. М. Хазиева // Агрохимический вестник. - 2018. - № 6. C. $57-60$.

12. Титов, Е. М. Применение водорастворимых комплексных удобрений на посевах яровой пшеницы/ Е. М. Титов, М. А. Внукова// Вестник ОрелГАУ. - 2011. - № 3. - С. 50-51.

13. Каталымов, М. Б. Микроудобрения: справочная книга по химизации сельского хозяйства. / М. Б. Каталымов. - Москва: Колос, 1980. - С. 149-158.

14. Панасин, В.Н. Изучение новых микроудобрений для подкормки озимой пшеницы / В. Н. Панасин, Д. А. Рымаренко // Агрохимический вестник. - 2013. - № 2 - С. 5-6.

15. Труфанова, А. А. Действие удобрений при некорневых подкормках и внутрипочвенном внесении на урожайность яровой пшеницы и химический состав зерна / А. А. Труфанова, О. А. Сорокина // Вестник КрасГАУ. - 2013. - № 5 - С. 108-113.

16. Доспехов, Б. А. Методика полевого опыта с основами статистической обработки результатов исследований (5-е изд., доп. и перераб.) / Б. А. Доспехов. - (5-е изд., доп. и перераб.) - Москва: Агропромиздат, 1986. - 351 с.

17. Методические рекомендации по проведению полевых опытов с кукурузой. - Днепропетровск, 1980. - 54 с.

18. Monica Markovic Jasna. Reaction of maize grain crop (ZEA mays L.) To water and nitrogen input into the environment of Eastern Croatia / Monica Markovic Jasna, Evangelina Pareja-Sánchez, Evangelina Pareja-Sánchez and other // Irrigation and Drainage. - 2017. - № 55. - P. 206-217.

19. Soil compaction and water content in soil during tillage and conventional tillage in irrigated maize: impact on grain yield / M, C Ramos, E Pareja-Sanchez, D Plaza Bonilla, C Cantero-Martinez, J Lampurlanes // Hydrological Processes. - 2019. - № 33. - P. 2095-2109.

\title{
UDC 633.15+631.8
}

DOI: $10.36461 /$ NP.2019.52.3.005

\section{CORN GRAIN PRODUCTIVITY, DEPENDING ON FOLIAR APPLICATION OF POLYNUTRIENT FERTILIZER}

\author{
P. A. Semina, Doctor Agricultural Sciences, professor; \\ I. V. Gavryushina, Candidate of Biological Sciences, associate professor
}

Federal State-Funded Educational Institution of Higher Education Penza State Agrarian University, Russia, t. (8412)628151, e-mail: seminapenza@rambler.ru

The article presents the results of studies on the effect of foliage treatment of crops with solutions of complex fertilizers Azosol 36 Extra and Aquarin 5 with micro-elements in chelate form on the structural elements and grain productuvity of early ripening and medium early maize hybrids at various levels of root nutrition. In the variants without mineral fertilizers, after applying complex fertilizers in the 5-leaf phase, the number of grains in the cob increased by $7.0-9.0 \%$, and after double treatment - by $8.0-$ $9.9 \%$, and there is no big difference in hybrids notably. On the fertilized soil, the treatment of crops in the 5-leaf phase of corn with micronutrient fertilizers allowed to increase the number of grains on the cob of the early ripening hybrid Ladoga $191 \mathrm{MB}$ by 7.2-7.5\%, and a double application increased the number of grains on cob by $7.8-8.1 \%$ When treating the crops of the mid-early hybrid Azosol 36 Extra, the growth of full-fledged grains amounted to 3.0-3.9 \%, and a greater number of grains were formed when microfertilizers were applied in the 5-leaf phase. Aquarin 5 contributed to an increase in the number of grains on the cob by 4.5-5.6\%, and the best results were obtained with its double use. After foliar treatment of early ripening hybrid crops with complex microelement fertilizers in the variants without solid mineral fertilizer, the weight of corn cobs increased by $6.4-11.1 \%$ with a slight advantage of using Aquarin 5. 
The use of Azosol 36 Extra on the crops of the Ronaldinio hybrid in a natural soil made it possible to increase the weight of grain from the cobs by 8.3-9.7\%, treatment with Aquarin $5-$ by $11.1-13.2 \%$, with large increases obtained after the double use of chelated fertilizer. The binary use of Azosol 36 Extra on the crops of the early ripening Ladoga hybrid $191 \mathrm{MV}$ under conditions of improved root nutrition contributed to an additional $8.2 \%$ of grain from a cob. Treatment in the 5-leaf phase and the double use of Aquarin 5 increased the weight of the grain of one cob by 8.6-8.7 \%. In the crops of the mid-early hybrid, the advantage was also for the Aquarin 5 microfertilizer. Its use in the 5-leaf phase increased the weight of the cob grain by $9.1 \%$, and its double use by $10.1 \%$. Azosol 36 Extra provided smaller grain increments - 5.2-6.2\%, moreover, the difference in treatment time was not significant. A promising way to increase the productivity of corn grain is to use complex fertilizer with microelements in the chelate form Aquarin 5 in the 5-leaf phase and double foliar treatment, which contributes to an increase in grain harvest from a unit area on an unapproved agricultural background by $9.6-12.4 \%$, and with the improvement of root nutrition conditions - by 7.7-8.8\%.

Keywords: corn, hybrid, fertilizers, microelements, corn cob, grain, productivity.

\section{Refecences:}

1. Drozdova, V. V. The influence of amount and combinations of mineral fertilizers on the yield of maize and agrochemical indicators of fertility of leached chernozem in the Western Pre-Ciscaucasian region / V. V. Drozdova, N. E. Redin // Scientific journal KubSAU. - 2016. - No. 121 (07). - P. 1732-1748.

2. Volkov, A. I. The productivity of early ripe maize hybrids in the conditions of Chuvashia / A. I. Volkov, N. A. Kirillov, L. N. Prokhorova // Feed production. - 2014. - No. 5. - P. 36-37.

3. Prokhorova, L. N. Improving the technology of cultivating corn for grain in the zone of sodpodzolic soils of the Volga region: the dissertation for the degree of Candidate of Agricultural Sciences: 06.01.01. - Cheboksary, 2015. - 146 p.

4. Makartsev, N. G. Feeding farm animals: a textbook for high schools / N. G. Makartsev. - 3rd ed., revised and add. - Kaluga: Noosphere, 2012. - 640 p.

5. The effectiveness of fertilizers in the cultivation of corn for grain in the conditions of the Southern Nonblack Soil Region: monograph / A. A. Moiseev A. V. Ivoilov, A. V. Sidorov [et al.]. - Saransk: Mordovia Publishing House. University, 2018. - 172 p.

6. Nikitin, V. V. Development of a legal framework for the consumption of grain corn nutrition elements in the Trans-Urals / V. V. Nikitin, V. V. Navalnev // Corn and Sorghum. - 2016. - No. 1. - P. 32-35.

7. Sotchenko, V. P. Corn cultivation technology / V. P. Sotchenko, V. N. Bagrintseva // Bulletin of the agricultural industry of Stavropol. - 2015. - Special issue No. 2. - P. 79-84.

8. Gaysin, I. A. Micronutrient fertilizers in modern agriculture / I. A. Gaisin, R. N. Sagitova, R. R. Khabibullin // Agrochemical Bulletin. - 2010. - No. 4. - P. 13-14.

9. Micronutrient fertilizers on a chelate basis: experience and prospects of use / E. Yu. Geiger, L. D. Varlamova, V. V. Semenov [et al.] // Agrochemical Bulletin. 2017. - No. 2. - P. 29-32.

10. Deriglazova, G. M. The value of foliar treatment with individual microelements and complex fertilizers for sowing grain crops / G. M. Deriglazova, O. A. Mitrokhina, N. N. Boeva // Agronomy. - 2010. No. 4. - P. 45-47.

11. Sidelnikov, N. I. Specific aspects of using micronutrient fertilizers on medicinal crops / N. I. Sidelnikov, R. R. Tkhaganov, F. M. Khazieva // Agrochemical Bulletin. - 2018. - No. 6. - P. 57-60.

12. Titov, E. M. The use of water-soluble complex fertilizers on crops of spring wheat / E. M. Titov, M. A. Vnukova // Bulletin of the Orel State Agrarian University. - 2011. - No. 3. - P. 50-51.

13. Katalymov, M. B. Microfertilizers: a reference book on the chemicalization of agriculture. I M. B. Katalymov. - Moscow: Kolos, 1980. - P. 149-158.

14. Panasin, V. N. The study of new micronutrient fertilizers for winter wheat / V. N. Panasin, D. A. Rymarenko // Agrochemical Bulletin. - 2013. - No. 2 - P. 5-6.

15. Trufanova, A. A. The effect of fertilizers by top dressing and subsoil application on the yield of spring wheat and the chemical composition of the grain / A. A. Trufanova, O. A. Sorokina // Bulletin of the KrasSAU. - 2013. - No. 5 - P. 108-113.

16. Dospekhov, B. A. The methodology of field experience with the basics of statistical processing of research results (5th ed., enlarged and corrected) / B. A. Dospekhov. - (5th ed., enlarged and corrected) - Moscow: Agropromizdat, 1986. - 351 p.

17. Methodological recommendations for conducting field experiments with corn. - Dnepropetrovsk, 1980. -54 p.

18. Monica Markovic Jasna. Reaction of maize grain crop (ZEA mays L.) To water and nitrogen input into the environment of Eastern Croatia / Monica Markovic Jasna, Evangelina Pareja-Sánchez, Evangelina Pareja-Sánchez and other // Irrigation and Drainage. - 2017. - № 55. - P. 206-217.

19. Soil compaction and water content in soil during tillage and conventional tillage in irrigated maize: impact on grain yield / M, C Ramos, E Pareja-Sanchez, D Plaza Bonilla, C Cantero-Martinez, J Lampurlanes // Hydrological Processes. - 2019. - № 33. - P. 2095-2109. 